\title{
Morphology of seeds and seedlings of four species of Vigna Savi (Leguminosae, Phaseolinae)
}

Fabiana Soledad Ojeda ${ }^{1}$, Patricia Susana Hoc ${ }^{1,2}$ and María Teresa Amela García ${ }^{1}$

Received: 14 August, 2012. Accepted: 28 June, 2013

\begin{abstract}
Four neotropical species of Vigna Savi (Leguminosae, Phaseolinae) have potential value as forage crops or ornamentals and could be cultivated in tropical or subtropical areas, even on floodplains. In order to obtain useful data for their culture and taxonomy, the seed morphology, germination pattern (hypogeal or epigeal) and seedling development were studied. The studied species belong to different sections of the genus: V. adenantha (G.F.W. Meyer) Maréchal, Mascherpa \& Stainier (Sect. Leptospron); V. candida (Vell.) Maréchal, Mascherpa \& Stainier (Sect. Sigmoidotropis); V. caracalla (L.) Verdc. (Sect. Caracallae) and V. luteola (Jacq.) Benth. (Sect. Vigna). The seeds were collected during fieldwork conducted in northwestern and northeastern Argentina. The qualitative and quantitative characters of the seeds were registered, after which they were sown. The development of the emerged seedlings was followed, first in a greenhouse and thereafter in open field. We recorded the type of germination, the thigmotropic movements of the hypocotyl and of the stem, seedling architecture and plant longevity. These traits allowed us to differentiate the species and construct an identification key that could be useful for agronomic or floricultural purposes. The data obtained partially support the current taxonomic treatment of the genus.
\end{abstract}

Key words: Vigna, seed morphology, germination, seedlings, Argentina

\section{Introduction}

In Argentina, the genus Vigna Savi (Leguminosae) is represented by eight species (Palacios \& Hoc 2001). The populations grow throughout the riparian forests from Misiones to Buenos Aires in the east and on the lower slopes of the subtropical cloud forests in the northwest; the former within the Paranaense Province and the latter within the Yungas Province, according to the phytogeographic regions defined by Cabrera (1976). In addition, populations of V. luteola have been recorded for disturbed sites from Salta to Córdoba, i.e., from northwestern to central Argentina (Hoc et al. 2007). Four species are economically important: V. adenantha and V. luteola are promising forage crops in subtropical or tropical areas (Fernández et al. 1988), even on floodplains, where their nitrifying properties are advantageous; and $V$. adenantha, $V$. candida and V. caracalla have potential value as ornamentals (Hoc \& Ojeda 2013; Etcheverry, unpublished data).

Considering the economical potential, knowledge of the seed morphology, germination process, seedling development and plant longevity is necessary in order to cultivate these species. Such knowledge could also contribute to clarifying the taxonomy of the group. Anatomical and morphological characters are useful for distinguishing among species at the seed stage (Corner 1976; Alsina 1988; Juan et al. 1998). The same is valid for seedlings, for various taxonomic levels, down to the level of subfamily (Silva \& Scatena 2011), genera (Rodriguez \& Tozzi 2008) or species (Dottori et al. 2000; Perícola et al. 2004; Mendiondo \& Amela García 2005). These characters can be employed to devise keys, such as those designed to categorize seeds or seedlings (Duke 1965, 1969; Csapody 1968) by family (Sánchez Sánchez \& Hernández Cepeda 2004), subfamily (Kirkbride et al. 2003) or genus (Deginani 2001), as well as those designed to differentiate among plants that grow in a certain region (Marino et al. 2008; Zamora-Cornelio et al. 2010).

Various authors have emphasized the taxonomic relevance of the morphology and anatomy of the seeds of legumes. De Candolle (1825) distinguished the systematic value of the curvature of the embryo. Capitaine (1912) differentiated the three subfamilies by morphological features, and Corner (1951) underscored those findings with anatomical studies. Recently, Kirkbride et al. (2003) and Ubiergo \& Lapp (2007) demonstrated the diagnostic value of seed characters at the generic and specific level. The seeds of Papilionoideae species have been described in many reports (Corner 1951, 1976; Gunn 1981; Alsina 1988; Kirkbride et al. 2003; Ubiergo \& Lapp 2007). Gunn (1981) differentiated

\footnotetext{
${ }^{1}$ Universidad de Buenos Aires, Facultad de Ciencias Exactas y Naturales, Departamento de Biodiversidad y Biología Experimental, Buenos Aires, Argentina

${ }^{2}$ Author for correspondence: patriciahoc@yahoo.com.ar
} 
the type of arils among this group. Despite these numerous contributions, the seeds of only two species of Vigna have been analyzed (Kirkbride et al. 2003), neither of which was from the neotropics.

Seedlings of legumes have been described by several authors. Compton (1912) related structure, size, form, habit and morphology within each species. Duke \& Polhill (1981) reviewed matters of ecology and systematics. Cotyledons of legumes can vary by morphology and function as well as in terms of their exposure at germination (Duke \& Polhill 1981). Smith (1981) assigned seedlings to different tribes within the Papilionoideae by cotyledon venation pattern. According to Ye (1983), the seedlings of Papilionoideae can be categorized by morphological type (Cinnamomum, Chimonanthus or Sophora). However, there is as yet little knowledge of the germination and seedling morphology of Vigna spp. The characters reported to date are the display of two opposite unifoliate primary leaves (Maréchal et al. 1978) and the hypogeal cotyledons (Maréchal et al. 1981).

Beyra \& Reyes Artiles (2004) pointed out that few characters can be used to distinguish the species within the genus Vigna; neither of them involved the seed nor the seedling in detail. The aim of the present work was to analyze the seed morphology, germination type, seedling development and plant longevity of four native species of Vigna in order to identify characters with taxonomic value.

\section{Materials and methods}

\section{Materials}

Seeds of Vigna adenantha (G.F.W. Meyer) Maréchal, Mascherpa \& Stainier (Sect. Leptospron), Vigna candida (Vell.) Maréchal, Mascherpa \& Stainier (Sect. Sigmoidotropis), Vigna caracalla (L.) Verdc. (Sect. Caracallae) and Vigna luteola (Jacq.) Benth. (Sect. Vigna) were collected during fieldwork conducted in northwestern and northeastern Argentina. The material was deposited in the Herbarium of the University of Buenos Aires and the Herbarium of the Instituto de Botánica Darwinion (codes, BAFC and SI, respectively; Thiers 2012) as follows (accession numbers precede herbarium codes):

Vigna adenantha: T. Meyer 755 (SI); E. Pueyrredón 17918 (SI); A. Schinini y C. Quarín 11545 (SI); P. Hoc 429 (BAFC); A. Burkart 7654 (SI).

Vigna candida: P. Hoc 404 (BAFC); A. Burkart 19597 (SI).

Vigna caracalla: A. Krapovickas et al. 28312 (SI); P. Hoc 403 (BAFC); A. G. Schulz 1188 (SI).

Vigna luteola: P. Hoc 401 (BAFC); P. Hoc 427, 428 (BAFC).

\section{Seed characters}

A quantitative-qualitative analysis of the seeds was performed before a germination experiment.
Quantitative characters. The length and width of thirty seeds of each species were measured under a stereoscopic microscope, with a metric scale; the thickness was measured with a Vernier caliper at the macroscopic scale.

For each quantitative character, ANOVA was performed using the GraphPad Prism 5 software.

Qualitative characters. The shape of the seeds, the hilum and the rim aril were described. The color was determined using the color chart devised by Kelly (1964).

To study the seed surface, the hilum and the rim aril were examined under scanning electron microscopy (SEM), the seeds were dehydrated in a graded ethanol series $(50,60$, $70,80,90$ and $100 \%)$, mounted on stubs, coated with goldpalladium alloy and observed with a field emission scanning electron microscope (Supra 40; Carl Zeiss, Oberkochen, Germany). The terminology employed to describe the seed surface follows Barthlott et al. (1998).

\section{Seedling characters}

Under laboratory conditions, we scarified the seeds by making a cut in the integument, placed them in Petri dishes previously prepared with a base of cotton and Whatman paper wetted with distilled water. After germination, the seedlings were transferred to pots containing $500 \mathrm{~mm}^{3}$ of soil perlite at 3:1. Seedling stage was set based on the appearance of the leaves. Seedling development was recorded until the first (trifoliate) second leaf expanded and the lateral branches of the main axis began to grow (after approximately one month). We recorded the emergency of the cotyledons, as well as the growth pattern and thigmotropic movements of the hypocotyl and the stem. The length of the epicotyl and the length and width of the primary leaves (pair of opposite unifoliate leaves) were measured with a metric bar made of graph paper. The branching system was described after the development of the first axillary bud. The plants were then transferred to the field and their growth habit was studied for three consecutive years to assess architecture and longevity.

\section{Results}

\section{Seed characters}

The significant differences among the species, in terms of the quantitative characters of seeds, are shown in Tab. 1.

Vigna adenantha. Seeds are 5.4-7.9 $(6.98 \pm 0.62) \mathrm{mm}$ long $\times$ 4.6-5.8 (5.09 \pm 0.31$) \mathrm{mm}$ wide $\times 2.8-4.9(3.41 \pm 0.46)$ $\mathrm{mm}$ thick, truncate-elliptic, rhomboid or broadly rhomboid, with rounded vertex. Smooth, dull, light olive brown (94 1. $\mathrm{OlBr}$ ) or moderate olive brown ( $95 \mathrm{~m}$. OlBr) surface. Elliptic hilum. Rim aril with a triangular or broadly triangular expansion. Micropyle in the center of a triangular depression. Triangular or narrowly triangular lens, lobes flat or slightly elevated (Fig. 1, 2). 
Table 1. ANOVA and Tukey's multiple comparison test of morphometric data related to the seeds of four Vigna species.

\begin{tabular}{|c|c|c|c|}
\hline Seed character & Vigna candida & Vigna caracalla & Vigna luteola \\
\hline Length & & $\mathrm{F}=65.91$ & \\
\hline Vigna adenantha & $8.71^{*}$ & 0.13 & $16.83^{*}$ \\
\hline Vigna candida & & $8.84^{*}$ & $8.12^{*}$ \\
\hline Vigna caracalla & & & $16.96^{*}$ \\
\hline Width & & $\mathrm{F}=415.9$ & \\
\hline Vigna adenantha & $28.82^{*}$ & $18.95^{*}$ & $14.25^{*}$ \\
\hline Vigna candida & & $47.78^{*}$ & $14.57^{*}$ \\
\hline Vigna caracalla & & & $33.20^{*}$ \\
\hline Thickness & & $F=63.05$ & \\
\hline Vigna adenantha & $14.91^{*}$ & 3.337 & 3.286 \\
\hline Vigna candida & & $18.25^{*}$ & $11.63^{*}$ \\
\hline Vigna caracalla & & & $6.623^{*}$ \\
\hline
\end{tabular}

SEM: In the seed (Fig. 9) the lax hilum cells disposed in uniseriate filaments (Fig. 10). Spirally arranged tubes developed in the rim aril (Fig. 11). Testa reticulate with quadrangular lumina (Fig. 12).

Vigna candida. Seeds are 4.7-6.3 (5.90 \pm 0.36$) \mathrm{mm}$ long $\times 2.4-3.0(2.68 \pm 0.12) \mathrm{mm}$ wide $\times 2.1-2.7(2.43 \pm 0.14) \mathrm{mm}$ thick, oblong, with slightly rounded vertex. Smooth, dull, light yellowish brown (76 l. yBr), dark orange-yellow (72 d. OY) or deep orange-yellow (69 deep OY), with scattered black (267 Bk) spots on the surface. Narrowly elliptic or narrowly oblong hilum, rim aril with a broadly triangular expansion, cleft at the apex. Micropyle situated at the edge of a spherical protuberance. Mounded, transversely elliptic lens, with a poorly developed groove (Fig. 3, 4).

SEM: In the seed (Fig 13) polyhedric densely disposed cells at the hilum near the rim aril (Fig. 14). The tubules of the seed coat are expanded and fused forming a reticulate pattern (Fig. 15). Testa surface perforate (lumina 1-2 $\mu \mathrm{m}$ in diameter) or fossulate (lumina $2 \mu \mathrm{m}$ long. $\times 1 \mu \mathrm{m}$ wide) (Fig. 16).

Vigna caracalla. Seeds are 6.1-7.7 $(6.99 \pm 0.40) \mathrm{mm}$ long $\times 6.1-7.7(6.68 \pm 0.37) \mathrm{mm}$ wide $\times 3.0-4.4(3.63 \pm 0.35) \mathrm{mm}$ thick, transversely elliptic or broadly oblong. Smooth, dull, deep yellowish brown ( 75 deep yBr), dark yellowish brown (78 d. yBr), deep brown (59 deep $\mathrm{Br}$ ) or deep reddish brown (44 deep rBr) surface, with light yellowish brown (761. yBr), medium yellowish brown ( $77 \mathrm{~m}$. yBr), deep reddish brown (44 deep $\mathrm{rBr}$ ), brownish orange (54 brO), strong reddish brown $(40 \mathrm{~s}$. rBr) or black (267 Bk) spots. Sunken hilum with a cushion-shaped structure, rim aril with a trapezoidal expansion with or without a cleft margin. Sunken micropyle in the same depression that contains the hilum. Conspicuous, heart-shaped lens (Fig. 5, 6).
SEM. In the seed (Fig. 17) the cells of the hilum are disposed in uniseriate compact filaments (Fig. 18). Differentiated filaments in the surface fuse forming the rim aril towards the hilum (Fig. 19). Testa reticulate and granulate (Fig. 20).

Vigna luteola. Seeds are 3.3-5.0 (4.42 \pm 0.50$) \mathrm{mm}$ long $\times 3.0-4.9(3.57 \pm 0.44) \mathrm{mm}$ wide $\times 2.3-3.5(3.02 \pm 0.22) \mathrm{mm}$ thick, elliptic, transversely oblong or ovate. Smooth, dull, black (267 Bk) or deep grayish yellow brown (81 deep Gyish yBr) surface. Narrowly elliptic, elliptic, narrowly ovate or narrowly oblong hilum. Rim aril without expansion. Small micropyle, on a dome. Conspicuous, heart-shaped lens (Fig. 7, 8).

SEM: The cells of the hilum are disposed in moniliform uniseriate to triseriate interwoven filaments (Fig. 22). In the seed (Fig. 21) the elements of the reticulum are fused in a strictly striate pattern towards the rim aril (Fig. 23). Reticulate-striate testa (Fig. 24).

\section{Seedling morphology}

Vigna adenantha. Phanero-epigeal germination, fleshy cotyledons (prioritizing nutrient storage over photosynthesis), epicotyl 21-116 (66.17 \pm 6.78$) \mathrm{mm}$ long, primary leaves $18-35(25.61 \pm 4.45) \mathrm{mm}$ long $\times 18-36(25.80 \pm 4.59) \mathrm{mm}$ wide, simple, broadly ovate with acute apex and cordate base. Straight epicotyl, stem with thigmotropic movements from the node of the primary leaves. Branches develop after the 15th second leaf is produced (Fig. 25).

Growth pattern: with thickened hypocotyl, pluriannual.

Vigna candida. Phanero-epigeal germination, fleshy cotyledons, epicotyl 21-116 (45.81 \pm 4.87$) \mathrm{mm}$ long, primary leaves 24-38 (30.52 \pm 3.54$) \mathrm{mm}$ long $\times 16-29(22.73 \pm 3.39)$ $\mathrm{mm}$ wide, simple, triangular to broadly triangular, with acute apex and cordate base. Straight epicotyl, stem with 

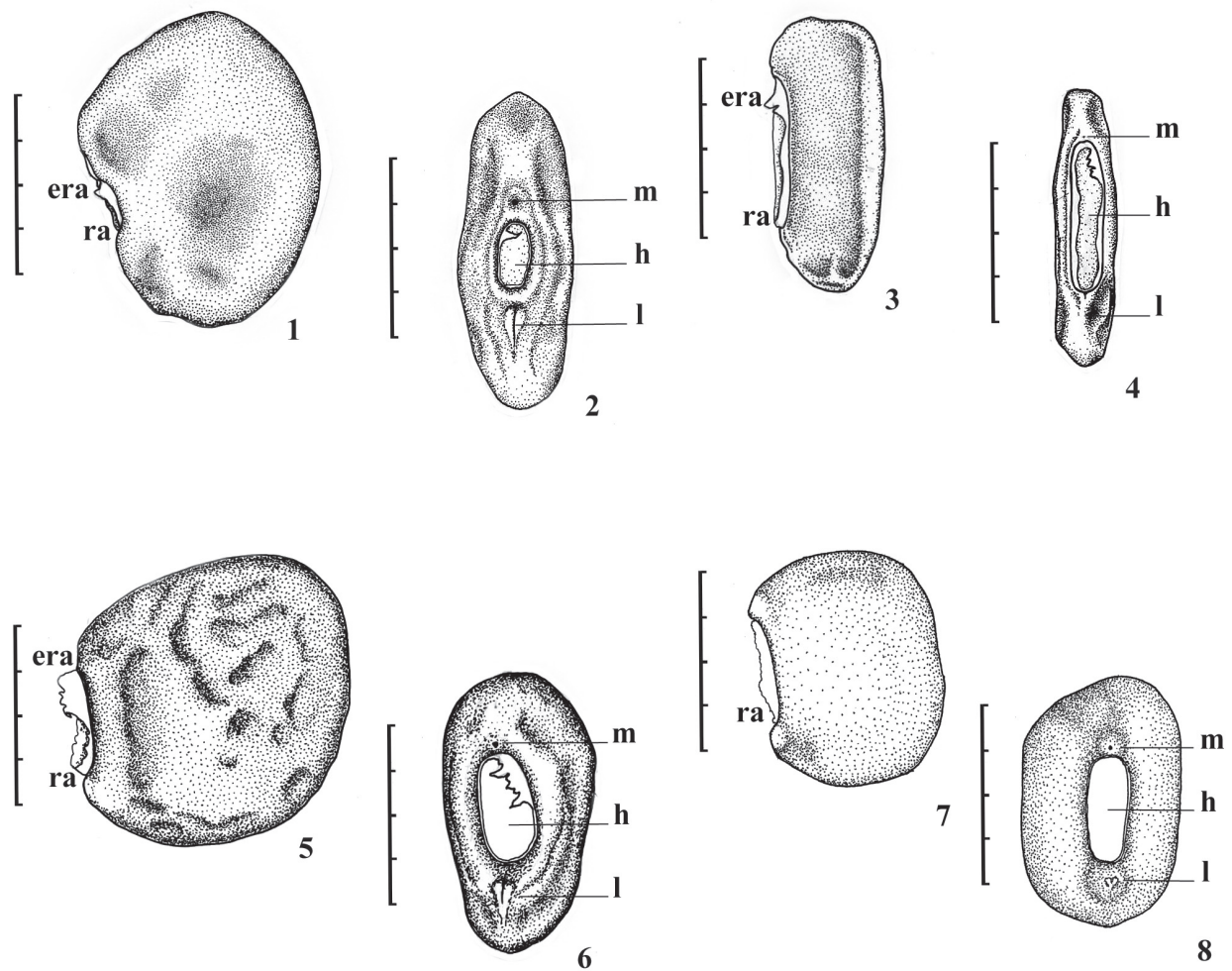

Figures 1-8. Morphology of the seeds of Vigna species. Lateral and hilar view, observed with stereoscopic microscope: 1-2. Vigna adenantha (G.F.W. Meyer) Maréchal, Mascherpa \& Stainier; 3-4. Vigna candida (Vell.) Maréchal, Mascherpa \& Stainier; 5-6. Vigna caracalla (L.) Verdc.; 7-8. Vigna luteola (Jacq.) Benth. Scale bars $=4 \mathrm{~mm}$.

era $=$ expansion of the rim aril, $\mathbf{h}=$ hilum, $\mathbf{l}=$ lens, $\mathbf{m}=$ micropyle, $\mathbf{r a}=$ rim aril.
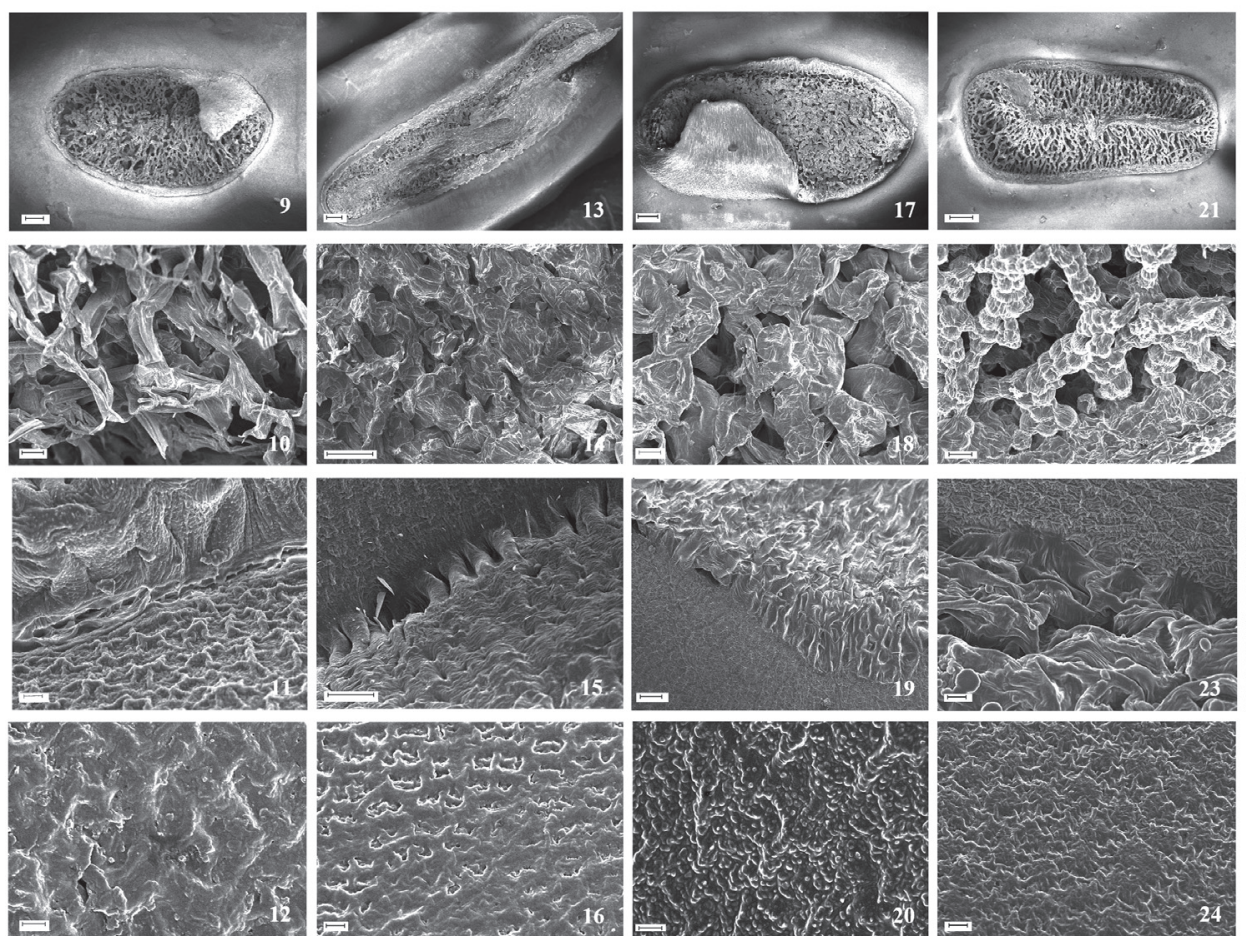

Figures 9-24. Surface topography of the seed with scanning electronic microscopy (SEM) of Vigna species: 9-12. Vigna adenantha (G.F.W. Meyer) Maréchal, Mascherpa \& Stainier; 13-16. Vigna candida (Vell.) Maréchal, Mascherpa \& Stainier; 17-20. Vigna caracalla (L.) Verdc.; 21-24. Vigna luteola (Jacq.) Benth.; 9,13,17,21. Hilum and rim aril; 10,14,18,22. Hilum cells (detail); 11,15,19,23. Transition from testa to rim aril; 12,16,20,24. Testa. Scale bars: 9,13,17,21 = $100 \mu \mathrm{m}$; $10,18,22,15,19=10 \mu \mathrm{m} ; 14=30 \mu \mathrm{m} ; 11,23,16,24=2 \mu \mathrm{m} ; 12,20=1 \mu \mathrm{m}$. 
briefly developed internodes between the primary leaves and the 5th-6th second leaves, with thigmotropic movements from the 6th node. Branches develop since the primary leaves are produced (Fig. 26).

Growth pattern: with thickened hypocotyl, pluriannual.

Vigna caracalla. Crypto-hypogeal germination, nutrient-rich cotyledons, epicotyl 30-83 $(37.56 \pm 8.84) \mathrm{mm}$ long, primary leaves $21-80(49.37 \pm 17.82) \mathrm{mm}$ long $\times 20-55$ (37.21 \pm 9.78$) \mathrm{mm}$ wide, simple, ovate, with emarginate apex and shortly attenuate or broadly triangular base. Straight epicotyl, stem with short internodes between the primary leaves and the 3rd second leaf, with thigmotropic movements from this node, not branched during the first year of development (Fig. 27). Primary leaves occasionally bifoliate of trifoliate rather than unifoliate.

Growth pattern: with thickened hypocotyl, pluriannual.

Vigna luteola. Crypto-hypogeal germination, nutrient-rich cotyledons, epicotyl 10.1-140 (110.08 \pm 5.80$)$ $\mathrm{mm}$ long, primary leaves $17-32(26.20 \pm 3.69) \mathrm{mm}$ long $\times 9-16(12.17 \pm 1.80) \mathrm{mm}$ wide, ovate, with acute apex and shortly attenuate base. Epicotyl with thigmotropic movements, stem with branches from the 10th second leaf (Fig. 28).

Growth pattern: without thickened hypocotyl, annual.

We based the key below on the seed and seedlings characters, as well as on the plant longevity of the species.

\section{Key to the species}

1. Annual growth pattern, without thickened hypocotyl, epicotyl with thigmotropic movements. Seed without an expansion of the rim aril. Testa reticulate-striate.

V. luteola (Sect. Vigna)

1'. Pluriannual growth pattern, with thickened hypocotyl, straight epicotyl, without thigmotropic movements. Seed with an expansion of the rim aril. Testa not reticulate-striate.

2. Seeds 2.4-3.0 (2.68 \pm 0.12$) \mathrm{mm}$ wide $\times 2.1-2.7(2.43 \pm 0.14) \mathrm{mm}$ thick, oblong. Straight stem, with briefly developed internodes between the primary leaves and the 5th-6th second leaves. Thigmotropic movements from the 6th node. Branches develop after the primary leaves are produced. Testa perforate-fossulate... V. candida (Sect. Sigmoidotropis) 2'. Seeds wider than 2.4-3.0 mm and thicker than 2.1-2.7 mm, truncate-elliptic, rhomboid or broadly rhomboid with rounded vertex, transversely elliptic or broadly oblong. Stem with thigmotropic movements from the node corresponding to the primary leaves or the 3rd second leaf. Branches develop from the 15th node, or branching does not occur. Testa not perforate-fossulate.

3. Seeds 4.6-5.8 (5.09 \pm 0.31$) \mathrm{mm}$ wide, surface without colored spots. Elliptic hilum, rim aril with a triangular or broadly triangular expansion. Phanero-epigeal germination. Stem with thigmotropic movements from the node corresponding to the primary leaves. Branches develop from the 15th second leaf. Primary leaves cordate at the base. Testa reticulate, lumina without granules

V. adenantha (Sect. Leptospron) 3'. Seeds 6.1-7.7 (6.68 \pm 0.37$) \mathrm{mm}$ wide, surface with colored spots. Sunken and cushioned hilum, rim aril with a trapezoidal expansion with its margin cleft or not. Crypto-hypogeal germination. Straight stem, with short internodes between the primary leaves and the 3rd second leaf, with thigmotropic movements from this node, not branched during the first year of development. Primary leaves shortly attenuate or broadly triangular at the base. Testa reticulate, lumina with granules.

V. caracalla (Sect. Caracallae)

\section{Discussion}

The seeds of all four species studied, except those of $V$. luteola, have an expansion of the rim aril, which corresponds to the dry tongue aril typified by Gunn (1981) for some Papilionoideae taxa.

The morphological characters of the seedlings of the studied species correspond to the usual ones in Phaseoleae enumerated by Duke \& Polhill (1981). The seedlings of $V$. caracalla and V. luteola can be assigned to the Cinnamomum type; and those of $V$. adenantha and $V$. candida can be assigned to the Sophora type (Ye 1983). Vigna luteola is assigned to a different subgenus than are the rest of the species, so these characters do not fit the actual infrageneric categories.
Occasional variation in the blade division of the primary leaves has also been observed for several species of Sesbania (Veasey et al. 1999). This could be a teratological case. Future studies will allow to corroborate or disallow this assumption.

Maréchal et al. (1981) mentioned that the germination type in the Phaseolus-Vigna complex allows the differentiation of the genera included in the group (epigeal in Phaseolus and hypogeal in Vigna). In contrast, in the present study, we identified both phanero-epigeal and crypto-hypogeal germination within Vigna. Duke (1969) stated that many genera have species with both germination types. Two of the species studied here, included in the subgenus Sigmoidotropis, exhibited phanero-epigeal germination, whereas the other two, included in the subgenera Sigmoidotropis and Vigna, exhibited crypto-hypogeal germination. Therefore, 


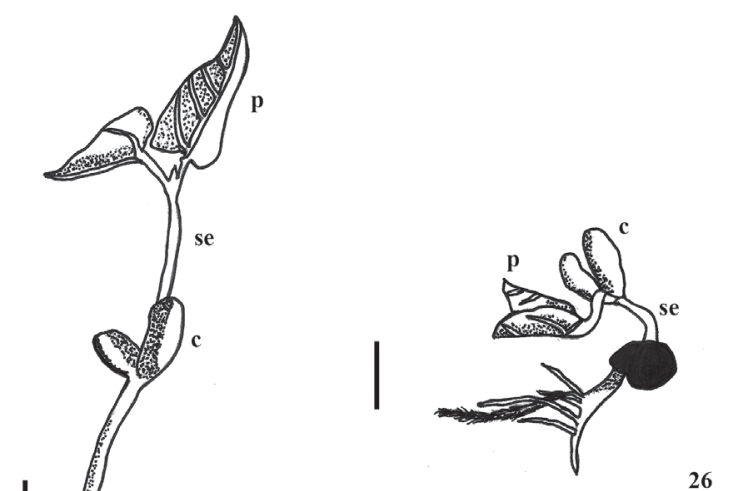

25
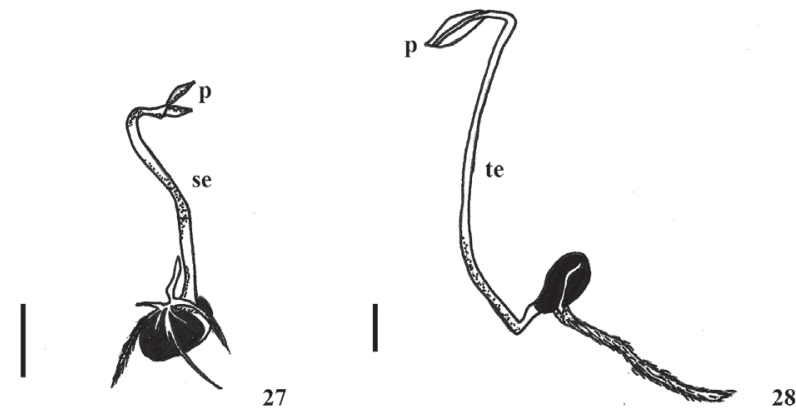

Figures 25-28. Morphology of the seedlings and type of germination of Vigna species: 25. Vigna adenantha (G.F.W. Meyer) Maréchal, Mascherpa \& Stainier; 26. Vigna candida (Vell.) Maréchal, Mascherpa \& Stainier; 27. Vigna caracalla (L.) Verdc.; 28. Vigna luteola (Jacq.) Benth.; 25,26. Epigeal germination; 27,28. Hypogeal germination. Scale bars: $25=6.98 \mathrm{~mm} ; 26=5.90 \mathrm{~mm} ; 27=6.99 \mathrm{~mm}$; $28=4.42 \mathrm{~mm}$.

$\mathbf{c}=$ cotyledons (nutrient storage turning photosynthetic), te = epicotyl with thigmotropic movements, $\mathbf{p}=$ primary leaves, $\mathbf{s e}=$ straight epicotyl.

germination type is not useful for distinguishing between Vigna and Phaseolus, not even for distinguishing between subgenera within Vigna.

Seed size and shape, as well as hilum shape, had diagnostic value at the species level, in accordance with the findings of Alsina (1988) and Paulino et al. (2010) for other genera of legumes, underscoring the importance of these characters for taxonomy in the family Fabaceae. Although the testa of all the species consists of crusts corresponding to the classification of Barthlott et al. (1998), its varied ornamentation was useful for differentiating among species, as in other Papilionoideae (Alsina 1988).

The seed characters that contributed to the differentiation of the studied Vigna species were the width, thickness, shape, as well as the presence and shape of the rim aril expansion and of the coat sculpturing. Although the coloration pattern also differed among species, this feature should be confirmed through studies of seeds from additional populations, as variation in this trait can occur within a single species, exemplified in various genera of legumes (Werker, 1997). Our SEM studies allowed us to describe the morphology of the testa in detail, as well as the transition from the seed coat to the rim aril. The seed characters described may be useful for agronomic purposes, such as seed recognition and quality analysis. Plant longevity also differed among species belonging to different subgenera, $V$. luteola (subgen. Vigna) being annual, whereas the other three species (subgen. Sigmoidotropis) were pluriannual. Further studies of this trait in more Vigna spp. are warranted in order to determine whether the genus merits subdivision. The germination type, the growth pattern of the seedlings during the first year of development and the (previously unknown) plant longevity are also relevant for future taxonomic, systematic and agronomic treatments.

\section{Acknowledgments}

The authors wish to thank the anonymous referees for their helpful comments. This work was supported by the Universidad de Buenos Aires (Grant no. UBACYT X100) and by the Argentine Consejo Nacional de Investigaciones Científicas y Técnicas (CONICET, National Council for Scientific and Technical Research; fellowship grant to FSO), for which PSH and MTAG are researchers.

\section{References}

Alsina, M. 1988. Estudio morfológico y anatómico de las semillas del género Ornithopus L. (Fabaceae). Acta Botánica Malacitana 13: 171-178.

Barthlott, W.; Neinhuts, C.; Cutler, D.; Ditsch, F.; Meusel, I.; Theisen, I. \& Wilhelmi, H. 1998. Classification and terminology of plant epicuticular waxes. Botanical Journal of the Linnean Society 126: 237-260.

Beyra, A. \& Reyes Artiles, G. 2004. Revisión taxonómica de los géneros Phaseolus y Vigna (Leguminosae-Papilionoideae) en Cuba. Anales del Jardín Botánico de Madrid 61(2): 135-154.

Cabrera, A.L. 1976. Enciclopedia argentina de agricultura y jardinería. Tomo II: Regiones fitogeográficas argentinas. Buenos Aires, ACME.

Capitaine, L. 1912. Les graines des Légumineuses. Paris, Larose-Lechevalier.

Compton RH. 1912. An investigation of the seedling structure in the Leguminosae. The Journal of the Linnean Society (Botany) 41: 1-122.

Corner, E. 1951. The Leguminous seed. Phytomorphology 1: 117-150.

Corner, E. 1976. The seeds of Dicotyledons. Vol. I. Cambridge, Cambridge University Press.

Csapody, V. 1968. Keimlings-Bestimmungsbuch der Dikotyledonen. Budapest, Akadémiai Kiadó.

De Candolle, A. 1825. Mémoires sur la Famille des Légumineuses. Paris, A. Belin,.

Deginani, N.G. 2001. Las especies argentinas del género Passiflora (Passifloraceae). Darwiniana 39: 43-129.

Dottori, N.; Bruno, Gloria \& Cosa, M.T. 2000. Anatomía comparada de las plántulas de Solanum elaeagnifolium y Solanum juvenale (Solanaceae). Boletín de la Sociedad Argentina de Botánica 35 (1-2): 115-23.

Duke, J.A. 1965. Keys for the identification of seedlings of some prominent woody species in 8 forest type in Puerto Rico. Annals of the Missouri Botanical Garden 52: 314-350.

Duke, J.A. 1969. On tropical tree seedlings. 1. Seeds, seedlings, systems, and systematics. Annals of the Missouri Botanical Garden 56: 125-161. 
Duke, J.A. \& Polhill, R.M. 1981. Seedlings of Leguminosae. Pp. 941-949. In: Polhill, R.M \& Raven, P.H. (Eds). Advances in Legume Systematics. Vol. II, Kew, Royal Botanic Gardens.

Fernández, J.G.; Benítez; C.A; Picio, R.M. \& Royo Pallares, O. 1988. Leguminosas forrajeras nativas del este de la provincia de Corrientes. Serie técnica № 26. EEA Mercedes INTA.

Gunn, Ch. 1981. Seeds of Leguminosae. Pp. 913-925. In: Polhill. M. and Raven P. (Eds.) Advances in Legume Systematics. Vol. II. Kew, Royal Botanic Gardens.

Hoc, P.S.; Palacios, R.A. \& Mom, M.P. 2007. Novedades en especies de Vigna e Inga (Leguminosae) para la Argentina. Boletín de la Sociedad Argentina de Botánica 41: 331-332.

Hoc, P.S. \& Ojeda, F.S. 2013. Two species of Vigna (Leguminosae, Phaseolinae) with ornamental potential native to Argentina: $V$. adenantha and V. candida. Acta Horticulturae (In press)

Juan, R., Fernández, I. \& Pastor, J. 1998. Aportación a la morfología y anatomía de frutos y semillas del género Digitales L. en el suroeste de España. Lazaroa 19: 17-28.

Kelly, K. 1964. Color name charts illustrated with centroid colors. Supplement to NBS circular 553. Inter-Society Color Council - National Bureau of Standards (ISCC-NBS). U. S. National Bureau of Standards.

Kirkbride, J.H.; Gunn, C.R. \& Weitzman, A.L. 2003. Fruits and seeds of genera in the subfamily Faboideae (Fabaceae). Tech. Bull. 1890. United States Department of Agriculture. Washington DC, Agricultural Research Service.

Maréchal, R; Mascherpa, J.M. \& Stainier, F. 1978. Etude taxonomique d'un groupe complexe d' espèces des genres Phaseolus et Vigna (Papilionaceae) sur la base de données morphologiques et polliniques, traitées par l'analyse informatique. Boissiera 28: 1-273.

Maréchal, R; Mascherpa, J.M. \& Stainier, F. 1981. Taxonometric study of the Phaseolus- Vigna complex and related genera. Pp. 329-335. In: Pollhill, R. M. \& Raven, P. H. (Eds.). Advances in Legume Systematics. Vol. I. Kew, Royal Botanic Gardens.

Marino, G.D.; Mas, M.V. \& Orlandoni, M.J. 2008.Morfología y reconocimiento de las principales especies leñosas nativas de la provincia de Santa Fe, Argentina, en el estado de plántula. Boletín de la Sociedad Argentina de Botánica 43(1-2): 67-81.

Mendiondo, G., Amela García, M. T. 2005. Exomorfología de plántulas de Passiflora spp. (Passifloraceae). Boletín de la Sociedad Argentina de Botánica 40(Supl.): 71.
Palacios, R.A. \& Hoc, P.S. 2001. Phaseoleae. Flora fanerogámica Argentina. Fasc. 75, 128. Fabaceae, parte 12. Buenos Aires, CONICET.

Paulino, V.J., Pessine, E. \& Teixeira, S.P. 2010. Estudos morfoanatômicos da semente e da plântula de espécies de Anileiras (Indigofera L., Leguminosae). Acta Botanica Brasilica 24(1): 1-7.

Perícola, N.; Dottori, N.; Cosa, M.T.; Bruno, G. \& Hadid, M. 2004. Estudio morfoanatómico de la plántula de Solanum palinacanthum (Solanaceae). Boletín de la Sociedad Argentina de Botánica 39(1-2): 67-73.

Rodrigues, R.S., Tozzi, A.M.G.A. 2008. Systematic relevance of seedling morphology in Acosmium, Guianodendron, and Leptolobium (Leguminosae, Papilionoideae). Brittonia 60(3): 287-296.

Sánchez Sánchez, O. \& Hernández Zepeda, C. 2004. Estudio morfológico de plántulas de la familia Bombacaceae en Quintana Roo, México. Foresta Veracruzana 6(2): 1-6.

Silva, I.V. \& Scatena, V.L. 2011. Morfologia de sementes e de estádios iniciais de plântulas de espécies de Bromeliaceae da Amazônia. Seed morphology and early seedling stages in Bromeliaceae from the Amazon. Rodriguésia 62(2): 263-272.

Smith, D.L. 1981. Cotyledons of the Leguminosae. Pp. 927-940. In: Polhill, R.M. \& Raven, P.H. (Eds.). Advances in Legume Systematics. Vol. II. Kew, Royal Botanic Gardens.

Thiers, B. 2012. Index Herbariorum: A global directory of public herbaria and associated staff. New York Botanical Garden's Virtual Herbarium. http://sweetgum.nybg.org/ih/

Ubiergo, P. \& Lapp, M. 2007. Caracterización morfológica de semillas de algunas especies de los géneros Cassia L. y Senna Mill. (Leguminosae Juss.). Revista de la Facultad de Agronomía (LUZ) 24: 426-441.

Veasey, E.A.; Negrão, M.O.; Martins, P.S \& Bandel, G. 1999. Early growth and seedling morphology of species of Sesbania Scop. (Leguminosae, Robinieae). Scientia Agricola 56: 329-335.

Werker, E. 1997. Seed anatomy. 1st ed. Berlin, Borntraeger.

Ye, N.G. 1983. Studies on the seedling types of dicotyledonous plants (Magnoliophyta, Magnoliopsida). Phytologia 54: 161-189.

Zamora-Cornelio, L.F.; Ochoa-Gaona, S.; Vargas Simón, G.; Castellanos Albores, J. \& Jong, B.H.J. 2010. Germinación de semillas y clave para la identificación de plántulas de seis especies arbóreas nativas de humedales del sureste de México. Revista de Biología Tropical 58(2): 717-732. 